\title{
ANALISIS SISTEM PELAKSANAAN PENGHITUNGAN PAJAK ATAS KENDARAAN BERMOTOR DALAM MENINGKATKAN PAJAK DAERAH DI KANTOR SAMSAT GUNUNG SITOLI
}

\author{
Maria Magdalena Bate'e \\ Sekolah Tinggi Ilmu Ekonomi Pembangunan \\ Jl. Karet No. 30 Kelurahan llir Kecamatan Gunungsitoli \\ Kota Gunungsitoli 22815 \\ maria.batee82@gmail.com / \\ maria.magdalena@stiepembnas.ac.id
}

\begin{abstract}
ABSTRAK
Pajak Kendaraan Bermotor (PKB) merupakan penyelenggaraan pajak daerah atas kendaraan bermotor. Yang menjadi Objek pajak kendaraan bermotor yaitu bukti kepemilikan atau kuasa atas kendaraan bermotor, sedangkan Subjek pajak kendaraan bermotor yaitu orang pribadi ataupun badan yang memiliki atau menguasai kendaraan bermotor. Adapun tujuan dari penelitian ini yaitu untuk mengetahui sistem pelaksanaan perhitungan pajak kendaraan bermotor (PKB) Roda 2 pada Kantor Sistem Administrasi Manunggal Satu Atap (SAMSAT) Gunungsitoli. Jenis penelitian dalam penelitian ini menggunakan jenis penelitian deskriptif kualitatif dengan teknik pengumpulan data observasi dan wawancara. Dari hasil penelitian diketahui bahwa perhitungan PKB Roda 2 di kantor Samsat Kota Gunungsitoli telah dilaksanakan sesuai dengan perpajakan di Indonesia dengan mengacu pada UU No 28 Tahun 2009 tentang Pajak Daerah Dan Retribusi Daerah (PDRD) dan juga Peraturan Daerah Provinsi Sumatera Utara Nomor 1 Tahun 2015 tentang Pajak Daerah Provinsi Sumatera Utara. Dalam sistem Pemungutan PKB Roda 2 di kantor SAMSAT Gunungsitoli dilaksanakan dengan Official Assessment System yang artinya bahwa pemungutan pajak didasarkan atas ketetapan Kepala Daerah dengan cara menggunakan SKPD (Surat Ketetapan Pajak Daerah) dan/atau dokumen-dokumen lain yang dipersamakan berupa karcis dan nota perhitungan, penetapan oleh petugas kantor SAMSAT, dan pembayarannya dilakukan oleh Wajib Pajak dan disetor oleh petugas ke Bank yaitu Bank SUMUT Cabang Gunungsitoli.
\end{abstract}

Kata kunci : Pajak Kendaraan Bermotor, Pajak Daerah

\section{PENDAHULUAN}

\section{Latar Belakang Penelitian}

Dalam memungut pajak kendaraan bermotor merupakan upaya dalam menambahkan Pendapatan Asli Daerah yang termasuk atau tergolong dalam Pajak Provinsi atau Pajak Daerah. Sebagai salah satu sumber penghasilan 
daerah yang besar pajak kendaraan bermotor yang merupakan Pajak Daerah yang memerlukan perhatian khusus dari Pemerintah Daerah untuk terus menerus meningkatkan pengelolaan pajak tersebut. Sesuai dengan UU No. 28 tahun 2009 mengenai Pajak Daerah dan Retribusi Daerah, dimana disebutkan bahwa pajak kendaraan bermotor merupakan pajak atas hak pemilik atau penguasa atas kendaraan bermotor. Kendaraan bermotor dalam hal ini yaitu semua kendaraan yang beroda dua ataupun lebih yang digunakan disemua jenis jalan darat dan digerakkan dengan alat teknik berupa mesin atau motor atau peralatan lain yang fungsinya mengubah sumber daya energi tertentu menjadi tenaga gerak kendaraan bermotor yang bersangkutan, termasuk alat-alat besar yang juga dapat bergerak atau berpindah. Dalam menjalankan otonomi daerah, pemerintah daerah memiliki hak, kewenangan, dan kewajiban untuk mengurus sendiri pemerintahannya ataupun masyarakatnya secara khusus dalam menjalankan kebijakan Desentralisasi. Dasar dari pelaksanaan perpajakan kendaraan bermotor yaitu Undang-Undang No. 28 Tahun 2009 tentang pajak daerah dan retribusi daerah. Untuk meningkatkan PAD (Pendapatan Asli Daerah) maka pemerintah daerah harus maksimal dalam menerapkan kebijakan pemungutan pajak progresif untuk kepemilikan kendaraan bermotor. Kebijakan ini juga diharapkan dapat mengurangi penggunaan kendaraan bermotor di kota-kota besar sebagai salah satu penyebab naiknya tingkat kemacetan arus lalu lintas dan terhitung sejak tanggal 02 Mei 2011 tarif pajak progresif diberlakukan di wilayah provinsi sumatera utara. Pemerintah Provinsi mendapatkan keleluasaan serta kebebasan penuh dalam menetapkan PKB (Pajak Kendaraan Bermotor). PKB yakni Pajak Daerah merupakan pendapatan Daerah yang sangat besar sehingga pengelolaan pemungutan dan pengurusan PKB dilakukan oleh Pemerintah Daerah yang difokuskan pada satu lokasi dimana melibatkan unsur-unsur terkait di dalam pengelolaannya. Pelaksanaan pemungutan pajak kendaraan bermotor dilaksanakan oleh kantor Sistem Administrasi Manunggal Satu Atap yang selanjutnya disingkat dengan SAMSAT, di mana di dalamnya terdapat hubungan kerjasama beberapa pihak yaitu Kepolisian Negara Republik Indonesia, pemerintah daerah (Dinas Pendapatan Daerah) dan PT Jasa Raharja (Persero). Pihak Kepolisian memiliki fungsi dan kewenangan dalam bidang registrasi dan pengidentifikasian kendaraan bermotor, Dinas Pendapatan Daerah berfungsi dalam bidang pemungutan PKB dan BBNKB dan PT. Jasa Raharja (Persero) berwenang dalam bidang penyampaian Sumbangan Wajib Dana Kecelakaan Lalu Lintas Jalan (SWDKLLJ). Kantor SAMSAT dibentuk agar dapat memberikan kemudahan pelayanan bagi masyarakat dan menjadi perpanjangan tangan pemerintah daerah dalam pemungutan PKB. Masalah yang ditemukan pada kantor SAMSAT Gunungsitoli adalah banyaknya penunggakan pembayaran PKB. Berdasarkan informasi yang didapatkan pada tanggal 13 juni 2015 di kantor SAMSAT Gunungsitoli bahwa Pemerintah Daerah Provinsi Sumatera Utara melalui SAMSAT Gunungsitoli memberikan dispensasi dan penghapusan sanksi administrasi PKB dan BBN (Bea Balik Nama) terhadap kendaraan bermotor. Hal itu dinyatakan oleh Kepala UPT Dinas Pendapatan Provinsi Sumatera Utara Gunungsitoli ELIZARO ZEBUA. Dispensasi yang dilakukan 
dalam hal ini yaitu penghapusan sanksi daripada administrasi pajak bermotor dan juga administrasi BBN kendaraan bermotor yang diberlakukan di wilayah Nias berdasarkan surat Peraturan Gubernur Sumatera Utara No.45 Tahun 2014, tentang pemberian keringanan dan penghapusan denda administrasi PKB/BBNKB. Jadi bagi masyarakat (wajib pajak kendaraan bermotor) terdapat belum melunasi pajak kendaraan bermotor miliknya baik yang hampir selama sepuluh tahun menunggak diberikan waktu selama bulan Desember 2014 untuk melakukan pemutihan yaitu hanya membayar tunggakan pokok selama dua tahun saja. Artinya, pemilik kendaraan yang menunggak sampai beberapa tahun lamanya dapat menghidupkan atau mengaktifkan kembali STNK-nya dengan hanya membayar PKB tahun 2013 dan 2014 tanpa denda. Selain itu, pemerintah juga membebaskan pokok Bea Balik Nama (BBN) tanpa dipungut biaya namun dengan syarat dan ketentuan yang berlaku. Namun meskipun sudah dilakukannya pemutihan tersebut masih terdapat sebagian masyarakat atau wajib pajak kendaraan bermotor (PKB) yang belum memenuhi tanggungjawab perpajakannya sehingga hal tersebut sangat mempengaruhi pendapatan asli daerah karena PKB adalah sumber penerimaan penghasilan daerah yang sangat besar. Masalah yang lain adalah kurangnya informasi yang diberikan kepada wajib pajak mengenai perhitungan PKB ketika wajib pajak membayar pajak, bila informasi perhitungan wajib pajak diberikan dengan benar ini akan mengurangi terjadinya pemungutan liar yang dilakukan oleh pihak-pihak tertentu. Dalam hal pemungutan pajak daerah termasuk PKB, pemerintah dalam daerah harus kontinyu dalam meningkatkan sistem pengelolaan keuangan daerah secara transparansi, partisipatif dan akuntabel, dan secara khusus pada pihak SAMSAT Gunungsitoli berkewajiban dalam memberikan informasi lengkap serta pelayanan yang terbaik kepada seluruh masyarakat yang berurusan dan dengan demikian masyarakat akan termotivasi dalam membayar pajaknya tepat waktu. Dari uraian dan fenomena di atas penelitian ini dilakukan dengan judul "ANALISIS SISTEM PELAKSANAAN PENGHITUNGAN PAJAK ATAS KENDARAAN BERMOTOR DALAM MENINGKATKAN PAJAK DAERAH DI KANTOR SAMSAT GUNUNGSITOLI".

\section{Identifikasi Masalah}

Penelitian ini memiliki identifikasi masalah yaitu bagaimana sistem dan prosedur dalam melaksanakan tata penghitungan pajak kendaraan bermotor (PKB) roda 2 yang sesuai dengan Peraturan Daerah yang berlaku.

\section{Tujuan Penelitian}

a. Untuk mengetahui mekanisme dan prosedur pendaftaran kendaraan bermotor baru, pemungutan PKB dan pembayaran PKB setiap tahun pada kantor SAMSAT Gunungsitoli.

b. Untuk mengetahui sistem dan mekanisme dari pelaksanaan perhitungan Pajak Kendaraan Bermotor (PKB) khususnya roda dua dalam meningkatkan pajak daerah. 
c. Untuk mengetahui apakah sistem dari pelaksanaan penghitungan Pajak Kendaraan Bermotor di kantor SAMSAT Gunungsitoli telah dilaksanakan sesuai dengan Peraturan Perundang-Undangan.

d. Untuk mengetahui upaya dalam menambah atau meningkatkan pemasukan pajak daerah melalui pemungutan Pajak Kendaraan Bermotor (PKB).

\section{Manfaat Penelitian}

Adapun manfaat penelitian ini adalah secara akademis dapat menyumbangkan ilmu pengetahuan dalam bidang ilmu akuntansi dan perpajakan. Sedangkan manfaat secara praktis adalah :

a. menambah ilmu pengetahuan tentang Sistem Pelaksanaan Perhitungan Pajak Kendaraan Bermotor (PKB).

b. dapat memperoleh informasi dan evaluasi atas sistem yang telah dilaksanakan atau diterapkan dalam melaksanakan proses-proses tata cara perhitungan pajak kendaraan bermotor di kantor SAMSAT Gunungsitoli.

\section{TINJAUAN PUSTAKA}

\subsection{Pengertian Pajak}

Secara umum pengertian pajak berdasarkan Undang-Undang Nomor 16 Tahun 2009 pasal 1 ayat 1 "Pajak adalah kontribusi wajib kepada negara yang terutang oleh orang pribadi atau badan yang bersifat memaksa berdasarkan undang-undang, dengan tidak medapatkan imbalan secara langsung dan digunakan untuk keperluan negara bagi sebesar-besarnya kemakmuran rakyat." Selain itu pengertian pajak menurut Prof. Dr. Rochmat Soemitro, SH bahwa "pajak adalah iuran atau pungutan rakyat kepada pemerintah dengan berdasarkan undang-undang yang berlaku atau peralihan kekayaan dari sektor swasta kepada sektor publik yang dapat untuk dipaksakan serta yang langsung ditunjuk dan dipakai dalam pembiayaan yang diperlukan negara." Dari kedua pengertian tersebut di atas dapat ditarik kesimpulan bahawa pajak adalah merupakan iuran atau kontribusi yang bersifat dipaksakan sesuai dengan undang-undang yang berlaku yang bertujuan untuk keperluan negara.

\subsection{Fungsi dan Pengelompokkan Pajak}

Pajak memiliki fungsi yaitu fungsi anggaran (budgetair) dimana menjadi sumber dana bagi pemerintah dalam hal membiayai seluruh pengeluaran-pengeluarannya. Fungsi yang lain yaitu fungsi mengatur (cregulerend), maksudnya adalah alat yang mengatur atau melaksanakan kebijaksanaan pemerintah dalam bidang sosial dan ekonomi. Sedangkan pajak dikelompokkan menurut gologannya, sifatnya, dan lembaga pemungutannya. Bila menurut golongannya, pajak terdiri atas pajak langsung (ex. pajak penghasilan) dan pajak tidak langsung (ex. pajak pertambahan nilai). Menurut sifatnya, pajak terdiri atas pajak subjektif dan pajak objektif. Dan terakhir adalah menurut lembaga pemungutnya yaitu terdiri atas Pajak Pusat (pajak dipungut oleh 
pemerintah pusat) dan Pajak Daerah (pajak dipungut oleh pemerintah daerah).

\subsection{Pajak Daerah}

Pemungutan pajak daerah telah diatur dalam Undang-Undang Pajak Daerah dan Retribusi Daerah (PDRD) No. 28 tahun 2009. PDRD adalah pungutan oleh daerah yang merupakan salah satu hak daerah dalam menyelenggarakan otonomi daerah. Hak-hak daerah tersebut sebagaimana dimaksud dalam pasal 21 Undang-Undang Nomor 32 Tahun 2004 tentang Pemerintahan Daerah. Pelaksanaan UU PDRD di daerah diatur lebih lanjut dengan Peraturan Daerah (Perda).

Secara umum, Pajak Daerah adalah kontribusi wajib kepada daerah yang terutang oleh orang pribadi atau badan yang bersifat memaksa berdasarkan Undang-Undang, dengan tidak mendapatkan imbalan secara langsung dan digunakan untuk keperluan daerah bagi sebesarbesarnya kemakmuran rakyat. Selain itu, Pajak Daerah juga dapat diartikan sebagai suatu iuran yang wajib dilakukan oleh orang pribadi ataupun badan dalam suatu daerah dengan tidak adanya imbalan langsung yang seimbang dan sifatnya dapat dipaksakan berdasarkan peraturan undang-undang yang berlaku dan kegunaannya adalah untuk membiayai keperluan daerah dan pembangunannya. Sementara objek pajak daerah berasal dari segala sesuatu yang dikenakan oleh daerah sesuai dengan peraturan perundang-undangan yang berlaku, contohnya hotel, restoran, kendaraan bermotor, dan lain sebagainya.

\subsection{Pajak Kendaraan Bermotor (PKB)}

Pajak Kendaraan Bermotor adalah pajak atas kepemilikan dan atau penguasaan kendaraan bermotor. Kendaraan bermotor adalah semua kendaraan beroda beserta gandengannya yang digunakan di semua jenis darat, dan digerakkan oleh peralatan teknik berupa motor atau peralatan lainnya yang berfungsi untuk mengubah suatu sumber daya energi tertentu menjadi tenaga gerak kendaraan bermotor yang bersangkutan, termasuk alat-alat berat dan alat-alat besar yang dalam operasinya menggunakan roda dan motor dan tidak melekat secara permanen serta kendaraan bermotor yang dioperasikan di air. Pemungutan PKB dewasa ini didasarkan pada ketentuan dalam UU No. 28 Tahun 2009 Pasal 3-8.

Yang menjadi obyek pajak kendaraan bermotor adalah kepemilikan dan atau penguasaan kendaraan bermotor sebagai alat angkut orang atau barang. Pemilikan atau penguasaan kendaraan bermotor oleh pemerintah pusat dan pemerintah daerah, kedutaan, konsulat, perwakilan negara asing, perwakilan lembaga internasional, dikecualikan dari pengenaan pajak kendaraan bermotor. Kemudian yang menjadi subyek pajak kendaraan bermotor adalah orang pribadi atau badan yang memiliki dan atau menguasai kendaraan bermotor. Selanjutanya wajib pajak kendaraan bermotor adalah orang pribadi atau badan yang memiliki kendaraan bermotor.

\subsection{Sistem Pengenaan Pajak Kendaraan Bermotor (PKB)}


Dasar pengenaan PKB adalah hasil perkalian dari dua unsur pokok, yaitu :

a. Nilai Jual Kendaraan Bermotor (NJKB); dan

b. Bobot yang mencerminkan secara relatif tingkat kerusakan jalan dan atau pencemaran lingkungan akibat penggunaan kendaraan bermotor.

Khusus untuk kendaraan bermotor yang digunakan di luar jalan umum, termasuk alat-alat berat dan alat-alat besar serta kendaraan di air, dasar pengenaan PKB adalah NJKB.

\subsection{Tarif Dan Perhitungan Pajak Kendaraan Bermotor (PKB)}

Berdasarkan Undang-Undang Nomor 28 Tahun 2009 Pasal 6 ayat 1, besaran tarif pajak PKB untuk kendaraan bermotor pribadi ditetapkan sebagaimana di bawah ini :

a. Untuk kepemilikan kendaraan bermotor pertama paling rendah sebesar $1 \%$ (satu persen) dan paling tinggi sebesar $2 \%$ (dua persen);

b. Untuk kepemilikan kendaraan bermotor kedua dan seterusnya tarif dapat ditetapkan secara progresif paling rendah sebesar $2 \%$ (dua persen) dan paling tinggi sebesar $10 \%$ (sepuluh persen). Pajak progresif untuk kepemilikan kedua dan seterusnya dibedakan menjadi kendaraan roda kurang dari empat dan kendaraan roda empat atau lebih. Sebagai contoh orang pribadi atau badan yang memiliki satu kendaraan bermotor roda dua, satu kendaraan roda tiga, dan satu kendaraan bermotor roda empat; masing-masing diperlakukan sebagai kepemilikan pertama sehingga tidak dikenakan pajak progresif.

c. Kepemilikan kendaraan bermotor didasarkan atas nama dan atau alamat yang sama.

Selanjutnya pada Pasal 6 ayat 2-4 ditentukan bahwa tarif PKB untuk kendaraan bermotor angkutan umum, ambulans, pemadam kebakaran, sosial keagamaan, lembaga sosial dan keagamaan,

Pemerintah/TNI/POLRI, pemerintah daerah, dan kendaraan lain yang ditetapkan dengan peraturan daearah, ditetapkan paling rendah sebesar $0,5 \%$ (nol koma lima persen) dan paling tinggi sebesar $1 \%$ (satu persen). Adapun tarif PKB untuk kendaraan bermotor alat-alat berat dan alat-alat besar ditetapkan paling rendah sebesar $0,1 \%$ (nol koma satu persen) dan paling tinggi sebsar $0,2 \%$ (nol koma dua persen).

Dalam hal perhitungan pajak kendaraan bermotor, besaran pokok PKB yang terutang dihitung dengan cara mengalikan tarif pajak dengan dasar pengenaan pajak. Secara umum, perhitungan PKB adalah sesuai dengan rumus berikut :

Pajak Terutang

$$
\begin{array}{ll}
= & \text { Tarif Pajak } \times \text { Dasar Pengenaan Pajak } \\
= & \text { Tarif Pajak } \times(\text { NJKB } \times \text { Bobot })
\end{array}
$$

Contoh :

Apabila Orang Pribadi memiliki kendaraan roda dua sebanyak 2 (dua) unit dimana kendaraan pertama merek HONDA dan kendaraan kedua merek SUZUKI dengan NJKB Rp 18.400.000 dan Rp 15.600.000, dan 
memiliki kendaraan roda empat 1 (satu) unit jenis NISSAN dengan NJKB Rp 340.000.000. maka perhitungan PKB nya adalah :

$\begin{aligned} \text { Pajak Terutang merk HONDA } & =1 \% \times(\mathrm{Rp} 18.400 .000 \times 1,00) \\ & =\operatorname{Rp} 184.000 \\ \text { Pajak Terutang merk SUZUKI } & =2 \% \times(\mathrm{Rp} 15.600 .000 \times 1,00) \\ & =\operatorname{Rp} 312.000 \\ \text { Pajak Terutang merk NISSAN } & =1 \% \times(\mathrm{Rp} 340.000 .000 \times 1,00) \\ & =\operatorname{Rp} 3.400 .000\end{aligned}$

Dari hasil perhitungan PKB di atas diketahui bahwa jumlah pajak terutang yang dibayarkan untuk satu tahun masa pajak yaitu $\mathrm{Rp}$ 3.896.000. Kendaraan merek SUZUKI dikenakan tarif progresif karena merupakan kepemilikan yang kedua dari jenis kendaraan roda dua, sementara kendaraan roda empat tidak dikenakan karena merupakan kepemilikan pertama.

\subsection{Pemungutan Pajak Kendaraan Bermotor (PKB)}

Dalam masa transisi pemberlakuan Undang-Undang Nomor 28 Tahun 2009 dewasa ini, pemungutan PKB di Indonesia saat ini didasarkan pada dasar hukum yang jelas dan kuat, sehingga harus dipatuhi oleh masyarakat dan pihak yang terkait. Dasar hukum pemungutan PKB yang telah berlangsung saat ini adalah Undang-Undang Nomor 18 Tahun 1997 tentang Pajak Daerah dan Retribusi Daerah sebagaimana telah diubah dengan Undang-Undang Nomor 34 Tahun 2000 dan Peraturan Pemerintah Nomor 65 Tahun 2001 tentang Pajak Daerah. Berlakunya Undang-Undang Nomor 28 Tahun 2009 adalah sejak 1 Jaunuari 2010.

Sistem pemungutan pajak kendaraan bermotor adalah menggunakan Official Assessment System yaitu sistem pengenaan pajak yang dibayar oleh wajib pajak setelah terlebih dahulu ditetapkan oleh kepala daerah atau pejabat yang ditunjuk melalui Surat Ketetapan Pajak Daerah atau dokumen lain yang dipersamakan. Selain itu, PKB dilakukan bersamaan dengan penerbitan surat tanda nomor kendaraan bermotor (STNK) dan pemungutan pajak tahun berikutnya dilakukan di kas daerah atau bank yang ditunjuk oleh kepala daerah.

\section{METODE PENELITIAN Jenis Penelitian}

Penelitian ini menggunakan jenis penelitian Deskriptif dengan pendekatan kualitatif. Tahap-tahap dalam penelitian ini seperti gambar di bawah ini. 


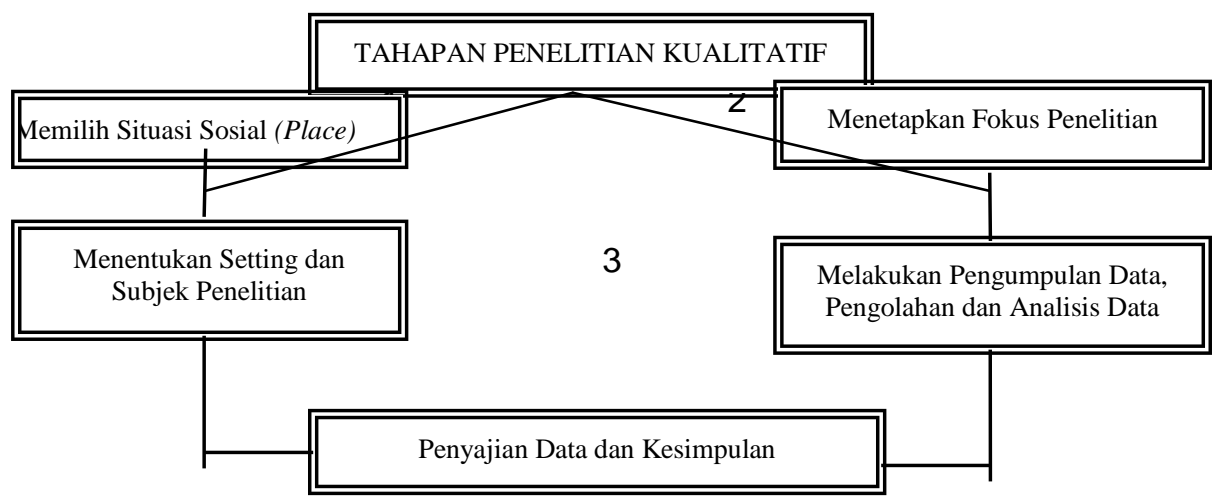

Gambar 1 Tahap-Tahap Penelitian Kualitatif

\section{Populasi Dan Sampel}

Adapun Populasi sekaligus Sampel dalam penelitian ini yaitu Perhitungan Pajak Kendaraan Bermotor (PKB) di Kantor SAMSAT Gunungsitoli.

\section{Teknik Pengumpulan Data}

Dalam hal teknik pengumpulan data, yang dilakukan untuk mengumpulkan data adalah :

1. Teknik Wawancara, yaitu wawancara terbuka dengan metode tanya jawab.

2. Teknik Observasi, yaitu peneliti akan terjun langsung ke lokasi penelitian dan mengamati atau mengawasi peristiwa yang terjadi di lokasi penelitian.

3. Teknik Dokumentasi, yaitu teknik dalam mengumpulkan data yang bersumber dari surat-surat atau tulisan-tulisan, karya-karya, foto, film, dll yang berguna untuk melengkapi penelitian.

\section{Teknik Analisa Data}

Berdasarkan teknik pengumpulan data yang diuraikan sebelumnya, maka data yang digunakan dalam penelitian ini adalah data primer dimana data langsung diperoleh dari hasil wawancara. Data berikutnya adalah data sekunder yaitu data yang diperoleh dari sumber yang lain.

Untuk mengolah data tersebut menjadi sebuah karya ilmiah yang sistematis maka digunakan Analisis Data Kualitatif yaitu suatu analisis data yang dilakukan sengan cara mengumpulkan, mengklasifikasi, menganalisis, serta menginterprestasikan data sehingga memberikan keterangan yang lengkap terhadap pemecahan masalah penelitian.

Menurut Miles dan Huberman (1992:20) yang dikutip oleh Sugiyono (2010) langkah dalam menganalisis data kualitatif dapat digambarkan sebagai berikut : 


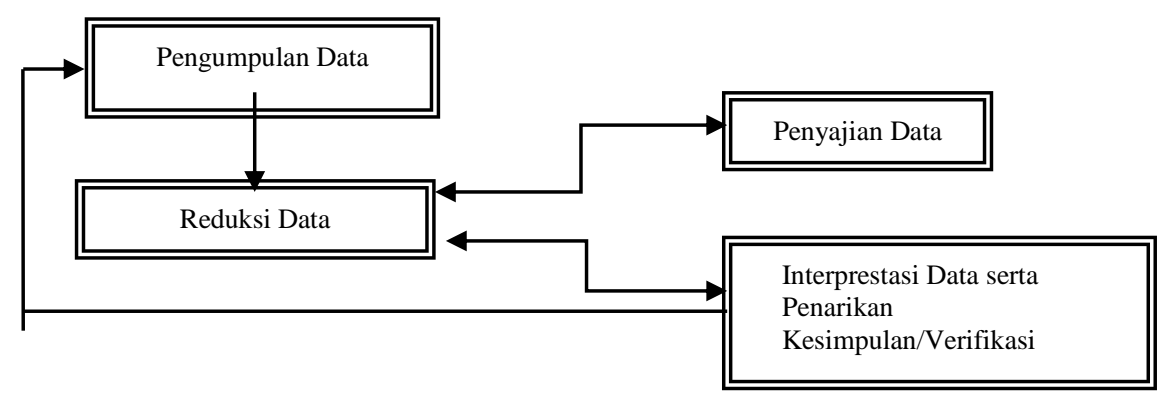

Gambar 2 Langkah-Langkah Analisis Data Penelitian Kualitatif

\section{HASIL PENELITIAN DAN PEMBAHASAN (12pt, bold)}

\subsection{Hasil Penelitian}

4.1.1. Pelaksanaan Pemungutan Pajak atas Kendaraan Bermotor di Kantor SAMSAT Gunungsitoli.

Kantor SAMSAT (Sistem Administrasi Manunggal Satu Atap) Gunungsitoli merupakan kantor yang menjadi unsur pelaksana teknis Pemerintah Daerah dalam bidang pajak kendaraan bermotor. SAMSAT merupakan gabungan dari 3 (tiga) instansi yaitu Kepolisian Resort Nias, Dinas Pendapatan Daerah dan PT. Jasa Raharja Cabang Gunungsitoli. Yang menjadi dasar dalam pemungutan PKB oleh SAMSAT gunungsitoli adalah Peraturan Daerah Provinsi Sumatera Utara Nomor 1 Tahun 2011 tentang Pajak Daerah yang didalamnya mengatur tentang pajak kendaraan bermotor serta acuannya tidak lain adalah UU No. 28 Tahun 2009 dan pelaksanaannya oleh keputusan bersama Direktur Lalu Lintas Kepolisian Daerah Sumatera Utara, Kepala Dinas Pendapatan Provinsi Sumatera Utara dan Kepala PT. Jasa Raharja (Persero) Cabang Sumatera Utara tentang Standar Pelayanan Publik Kantor SAMSAT Provinsi Sumatera Utara. Berdasarkan hasil pertemuan dan wawancara peneliti dengan Kepala Regident (Registrasi dan Identifikasi) Kantor SAMSAT Gunungsitoli bahwa kewenangan pemungutan pajak pada kantor SAMSAT Gunungsitoli terdiri dari dua yaitu :

1. PKB (Pajak Kendaraan Bermotor), dan

2. BBNKB (Bea Balik Nama Kendaraan Bermotor)

\subsubsection{Subjek dan Objek PKB Pada Kantor Samsat Gunungsitoli}

Subjek PKB pada kantor Samsat Gunungsitoli yaitu oarng pribadi atau badan yang memiliki kendaraan bermotor. Yang menjadi subjek PKB dikantor Samsat Gunungsitoli yaitu : 
1. Orang pribadi

2. Umum (CV dan perusahaan)

3. Instansi pemerintah

Objek pajak dikantor Samsat Gunungsitoli merupakan PKB yang dipungut. Jenis objek pajak tersebut antara lain yaitu :

1. Sedan dan/atau sejenisnya

2. Jeep dan/atau sejenisnya

3. Minibus

4. Microbus

5. Pick up, light truck, truck, tangki dan sejenisnya

6. Station wagon dan sejenisnya

7. Sepeda motor Roda 2 dan Roda 3

4.1.3. Mekanisme dan Prosedur Pendaftaran Kendaraan Bermotor Baru Pada Kantor SAMSAT Gunungsitoli

Pendaftaran kendaraan baru di kantor SAMSAT Gunungsitoli ditentukan pada satu loket pendaftaran dan penerimaan berkas dengan menerapkan budaya antri. Petugas yang melayani wajib pajak pada loket ini adalah instansi kepolisian dimana bertugas dalam memeriksa kelengkapan berkas wajib pajak. Kelengkapan berkas yang harus dilengkapi oleh wajib pajak adalah :

1. Faktur pembelian kendaraan bermotor.

2. Bukti identitas pemilik kendaraan, apabila orang pribadi maka yang digunakan adalah KTP Asli dan Fotocopy. Apabila Badan Usaha maka yang digunakan adalah salinan akte pendirian, keterangan domisili, SIUP (Surat ljin Usaha Perdagangan) dan NPWP (Nomor Pokok Wajib Pajak) yang dilegalisasi. Apabila pemilik kendaraan tersebut adalah dari Instansi Pemerintah maka berkas yang harus disiapkan adalah surat tugas atau surat kuasa yang dimaterai dan telah ditandatangani oleh pimpinan serta dibubuhi cap instansi yang terkait, selain itu adalah focopy KTP yang diberi kuasa.

3. Sertifikat uji tipe, tanda bukti uji tipe yaitu tanda bukti lulus uji berkala, sertifikan NIK (VIN) serta tanda pendaftaran tipe.

4. Surat keterangan bagi kendaraan bermotor angkutan umum yang telah memenuhi syarat rekomendasi dari Bupati/Walikota yang berada dalam wilayah Kabupaten/Kota setempat.

5. Kendaraan bermotor milik pemerintah dilengkapi surat keterangan tentang sumber dana pembelian dan biaya pemeliharaan yang tercantum dalam APBN/APBD dengan mencantumkan nomor kode rekening. 
6. Kendaraan bermotor milik TNI/POLRI dilengkapi surat keterangan yang berisi daftar kolektif kendaraan bermotor dari Panglima TNI, KASAT, KASAL, KASAU dan KAPOLRI, bila fotocopy dilegalisir oleh kesatuan yang mendaftarkan kendaraan bermotor tersebut.

7. Bukti hasil pemeriksaan cek fisik kendaraan bermotor.

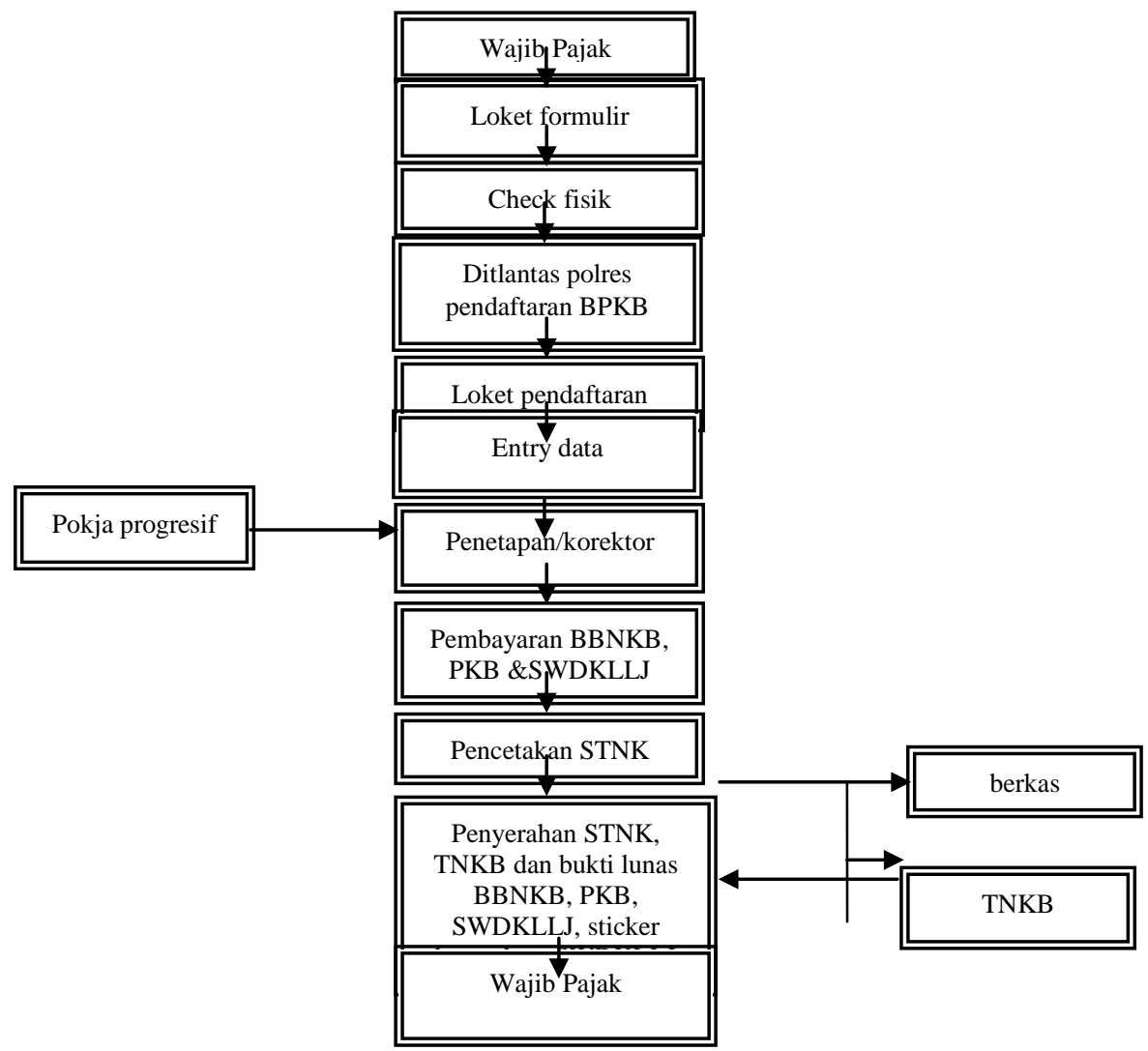

Gambar 3 Mekanisme dan Prosedur Pendaftaran

Kendaraan Bermotor Baru Pada Kantor Samsat Gunungsitoli

Berdasarkan gambar 3 di atas diketahui bahwa mekanisme dan prosedur pendaftaran kendaraan bermotor baru adalah sebagai berikut:

1. Pemilik kendaraan mengambil formulir pada loket yang telah tersedia dan melakukan pengisian data kendaraan bermotor pada formulir tersebut. 
2. Pemilik kendaraan membawa kendaraan bermotor beserta dokumen kelengkapan ke bagian cek fisik untuk digesek dan diperiksa nomor rangka dan nomor mesin masing-masing 2 lembar.

3. Pemilik kendaraan bermotor diarahkan ke Ditlantas Polres Nias untuk pendaftaran PKB.

4. Pemilik kendaraan bermotor menyerahkan dokumen kendaraan yang telah dilengkapi dengan blanko cek fisik, formulir permohonan STNK dan Nomor Register (Nomor Polisi) yang telah didapatkan dari bagian BPKB ke bagian pendaftaran untuk diteliti.

5. Petugas dari Dispenda akan mengentry data maksudnya melakukan perekaman data sesuai dengan dokumen kendaraan berrmotor dari Wajib Pajak.

6. Petugas dari Dispenda melakukan penetapan dan pokja progresif maksudnya memeriksa dokumen kendaraan bermotor untuk objek progresif pada data base (untuk menentukan urutan kepemilikan), menginformasikan dan menetapkan besarnya PKB, BBNKB serta SWDKLLJ.

7. Pemilik kendaraan bermotor membayar PNPB (Penerimaan Negara Bukan Pajak) yaitu STNK (Surat Tanda Nomor Kendaraan Bermotor) dan TNKB (Tanda Nomor Kendaraan Bermotor). Serta Bea Balik Nama Kendaraan Bermotor (BBNKB), Pajak Kendaraan Bermotor (PKB) serta SWDKLLJ sesuai dengan besarnya penetapan.

8. Petugas menyerahkan dan pemilik kendaraan menerima STNK, TNKB dan bukti pembayaran lunas BBNKB, PKB dan SWDKLLJ.

\subsubsection{Prosedur Pemungutan Pajak atas Kendaraan Bermotor di Kantor SAMSAT Gunungsitoli}

Adapun prosedur PKB yang berjalan di kantor SAMSAT Gunungsitoli dimulai terlebih dahulu pada tahap pendaftaran, penetapan, pembayaran dan tahap terakhir adalah penyetoran.

- Pendaftaran merupakan proses atau tahap pertama dalam pemungutan PKB sebelum wajib pajak membayar pajak, dalam tahap ini pemilik kendaraan mendatangi loket pendaftaran dan wajib mengisi formulir mengenai data-data kendaraan bermotor.

- Penetapan merupakan proses atau tahap selanjutnya dalam pemungutan PKB, pada tahap ini petugas kantor samsat melakukan entry data atau memasukkan data pemilik kendaraan/wajib pajak ke dalam data base dan menghitung semua kewajiban 
yang akan dibayarkan oleh pemilik kendaraan/wajib pajak.

- Pembayaran merupakan proses selanjutnya setelah petugas menghitung jumlah keseluruhan yang harus dibayar, maka wajib pajak melakukan pembayaran kepada kasir.

- Penyetoran merupakan proses yang terakhir dalam pemungutan PKB di mana pada tahap ini petugas kantor Samsat Gunungsitoli melakukan penyetoran uang PKB yang telah dipungut dalam satu hari kerja ke Bank Daerah yaitu Bank Sumut Cabang Gunungsitoli.

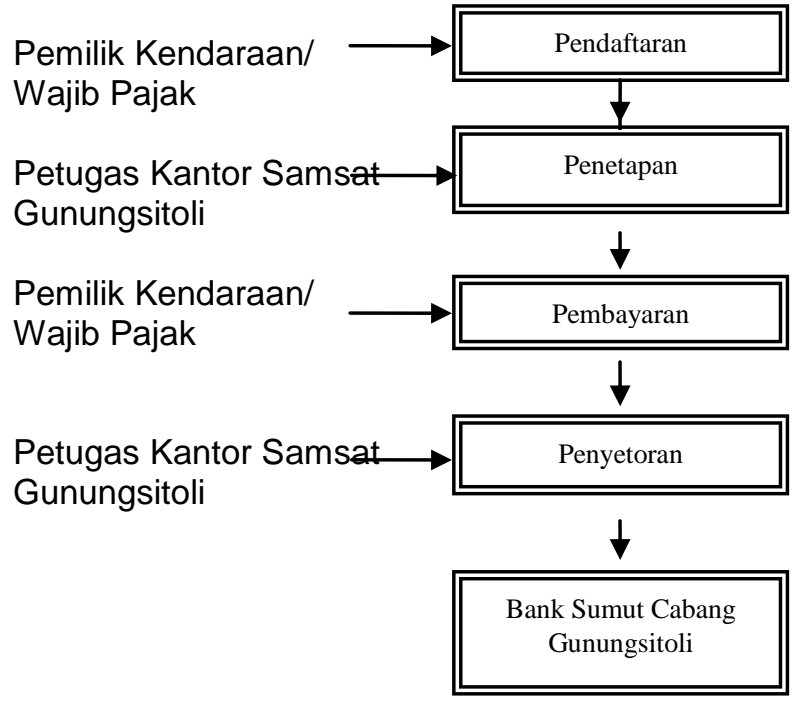

Gambar 4 Flow Chart Prosedur Pemungutan PKB Pada Kantor Samsat Gunungsitoli

4.1.5. Mekanisme dan Prosedur Pembayaran Pajak Kendaraan Bermotor (PKB) Setiap Tahun

Masa tahun pajak kendaraan bermotor yaitu 12 bulan terhitung mulai pada tahun pendaftaran kendaraan. Jadi pajak kendaraan bermotor dibayar setiap tahunnya. Kelengkapan berkas yang harus dipenuhi untuk membayar PKB yaitu:

- Bukti Identitas Diri Seperti KTP

- STNK Asli dan Fotocopy 
ISSN

2460-030X

Prosedur pembayaran yaitu :

1. Pemilik kendaraan bermotor datang kekantor samsat dan melakukan pendaftaran pada loket yang telah tersedia dengan menyerahkan persyaratan kebagian pendaftaran untuk diteliti oleh petugas.

2. Petugas yang berwenang melakukan entry data yaitu melakukan perekaman data sesuai dengan dokumen kendaraan bermotor dari wajib pajak.

3. Petugas yang berwenang melakukan penetapan dan pokja progresif dengan memeriksa dokumen kendaraan bermotor untuk objek progresif pada data base (untuk menentukan urutan kepemilikan), menginformasikan dan menetapkan besarnya PKB, BBNKB serta SWDKLLJ.

4. Pemilik kendaraan melakukan pembayaran Pajak Kendaraan Bermotor (PKB) serta SWDKLLJ sesuai besarnya penetapan kemudian pemilik daripada kendaraan bermotor akan menerima STNK (Surat Tanda Nomor Kendaraan) yang telah disahkan serta bukti lunas pembayaran PKB (Notice Pajak) dan SWDKLLJ.

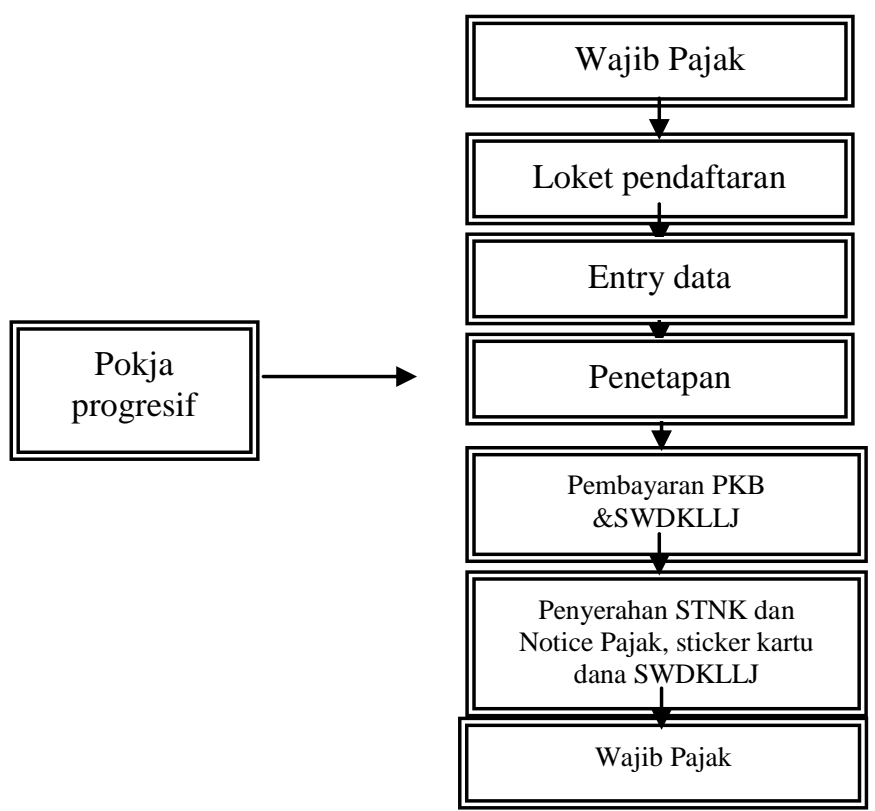

Gambar 5 Prosedur Pembayaran Pajak Kendaraan Bermotor Setiap Tahun Pada Kantor Samsat Gunungsitoli 


\subsection{Pembahasan}

4.2.1. Sistem Perhitungan Pajak Kendaraan Bermotor Pada Kantor Samsat Gunungsitoli Dalam Meningkatkan Pajak Daerah

Perhitungan PKB dikantor Samsat Gunungsitoli didasarkan pada Peraturan Daerah Provinsi Sumatera Utara Nomor 1 Tahun 2015 tentang Pajak Daerah Provinsi Sumatera Utara. Pekerjaan ini ditangani oleh pihak yang ditunjuk oleh instansi yaitu dari Kepolisian Resor Nias, Dispenda dan PT. Jasa Raharja Cabang Gunungsitoli. Pajak kendaraan bermotor yang telah dipungut oleh kantor Samsat Gunungsitoli setiap harinya disetor ke Bank Daerah yaitu Bank Sumut Cabang Gunungsitoli.

A. Tarif pajak kendaraan bermotor (PKB) yang diterapkan di kantor Samsat Gunungsitoli yaitu :

1. Tarif $(P K B)$ berdasarkan Subjek PKB yang dipungut di Samsat Gunungsitoli :

- 1,75 \% untuk kendaraan bermotor bukan umum atau kendaraan pribadi (warna plat hitam)

- $1 \%$ untuk kendaraan bermotor umum (plat warna kuning)

- $0,5 \%$ untuk kendaraan bermotor pemerintah, TNI/PLRI, ambulance, dan sosial keagamaan serta pemadam kebakaran (plat warna merah).

2. Tarif PKB Progresif untuk kendaraan penumpang Roda 4 dst Pribadi dan kendaraan Roda 2 yaitu :

- $2 \%$ untuk kepemilikan kedua

- $2,5 \%$ untuk kepemilikan ketiga

- $3 \%$ untuk kepemilikan keempat

- 3,5\% untuk kepemilikan kelima dan seterusnya naik 0,5\%

- Untuk Kendaraan bermotor milik pemerintah daerah (warna plat merah) tidak dikenakan tarif progresif.

3. Objek atau model kendaraan bermotor yang dikenakan tarif progresif meliputi :

- Sedan dan sejenisnya

- Jeep dan sejenisnya

- Minibus

- Microbus

- Pick up, light truck, truck, tangki dan sejenisnya

- Station wagon dan sejenisnya

- Sepeda motor Roda 2 dan Roda 3 
Apabila wajib pajak membayar PKB yang pertama atau pada saat mendaftarkan kendaraan bermotor, maka wajib pajak tersebut dikenakan Bea Balik Nama Kendaraan Bermotor (BBNKB). SWDKLLJ, biaya administrasi STNK dan Biaya administrasi TNKB yang ditetapkan oleh pemerintah daerah sebagai Penerimaan Negara Bukan Pajak.

Tarif BBNKB yang dikenakan kepada wajib pajak yaitu :

1. $15 \%$ untuk kendaraan bermotor bukan umum atau pribadi (warna plat hitam)

2. $15 \%$ untuk kendaraan umum (warna plat kuning)

3. $15 \%$ untuk kendaraan bermotor pemerintah, badan lembaga dan TNI/POLRI (warna plat merah).

Biaya STNK dan TNKB yaitu :

1. Biaya STNK Roda 4 umum Rp 50.000

2. Biaya STNK Roda $2 \& 3 \quad$ Rp 50.000

3. Biaya TNKB Roda $4 \quad$ Rp 50.000

4. Biaya TNKB Roda $2 \& 3 \quad$ Rp 30.000

B. Menghitung Besaran PKB khusus Roda 2

Tabel 1. Daftar NJKB (Nilai Jual Kendaraan Bermotor) Roda 2 


\begin{tabular}{|c|c|c|c|c|c|c|c|}
\hline $\begin{array}{l}N \\
0\end{array}$ & $\underset{G}{\text { KODIN }}$ & $\underset{\mathrm{K}}{\text { MERE }}$ & TYPE & $\begin{array}{c}\text { THN } \\
\text { BUA } \\
\text { T }\end{array}$ & $\begin{array}{l}\text { NJKB } \\
(\mathrm{Rp})\end{array}$ & $\begin{array}{c}\text { BOBO } \\
T\end{array}$ & $\begin{array}{c}\text { DP PKB } \\
\text { (Rp) }\end{array}$ \\
\hline 1 & & $\begin{array}{l}\text { YAMAH } \\
\text { A }\end{array}$ & N-MAX (2DP) & 2015 & $\begin{array}{l}21.200 .0 \\
00\end{array}$ & 1,0 & $\begin{array}{c}21.200 .0 \\
00\end{array}$ \\
\hline 2 & $\begin{array}{c}701421 \\
12949\end{array}$ & $\begin{array}{c}\text { YAMAH } \\
\text { A }\end{array}$ & BYSON (45P) & 2015 & $\begin{array}{c}16.900 .0 \\
00\end{array}$ & 1,0 & $\begin{array}{c}16.900 .00 \\
0\end{array}$ \\
\hline 3 & $\begin{array}{c}701421 \\
14349\end{array}$ & $\begin{array}{l}\text { YAMAH } \\
\text { A }\end{array}$ & $\begin{array}{c}\text { NEW V-IXION } \\
\text { (KICK } \\
\text { STARTER) } \\
\text { (1PA) }\end{array}$ & 2015 & $\begin{array}{c}18.800 .0 \\
00\end{array}$ & 1,0 & $\begin{array}{c}18.800 .00 \\
0\end{array}$ \\
\hline 4 & $\begin{array}{c}701421 \\
14449 \\
\end{array}$ & $\begin{array}{l}\text { YAMAH } \\
\text { A }\end{array}$ & $\begin{array}{r}\text { OLD V-I } \\
(3 \mathrm{C}\end{array}$ & 2015 & $\begin{array}{c}17.300 .0 \\
00\end{array}$ & 1,0 & $\begin{array}{c}17.300 .00 \\
0 \\
\end{array}$ \\
\hline 5 & $\begin{array}{c}701421 \\
13749\end{array}$ & $\begin{array}{c}\text { YAMAH } \\
\text { A }\end{array}$ & $\begin{array}{c}\text { JUPITER Z1 } \\
\text { CW (UE } 11 \\
\text { CW) }\end{array}$ & 2015 & $\begin{array}{c}12.400 .0 \\
00\end{array}$ & 1,0 & $\begin{array}{c}12.400 .00 \\
0\end{array}$ \\
\hline 6 & & SUZUKI & UD 110EE & 2015 & $\begin{array}{c}10.400 .0 \\
00\end{array}$ & 1,0 & $\begin{array}{c}10.400 .00 \\
0\end{array}$ \\
\hline 7 & $\begin{array}{c}701364 \\
32849\end{array}$ & SUZUKI & UH 200 & 2015 & $\begin{array}{l}42.400 .0 \\
00\end{array}$ & 1,0 & $\begin{array}{c}42.400 .00 \\
0\end{array}$ \\
\hline 8 & $\begin{array}{c}701364 \\
31649 \\
\end{array}$ & SUZUKI & UK125XCZ & 2015 & $\begin{array}{c}10.900 .0 \\
00\end{array}$ & 1,0 & $\begin{array}{c}10.900 .00 \\
0 \\
\end{array}$ \\
\hline 9 & $\begin{array}{c}701364 \\
31049\end{array}$ & SUZUKI & FU150SCDZ2 & 2015 & $\begin{array}{c}15.700 .0 \\
00\end{array}$ & 1,0 & $\begin{array}{c}15.700 .00 \\
0\end{array}$ \\
\hline 10 & $\begin{array}{c}701364 \\
29549\end{array}$ & SUZUKI & FU150SCD3 & 2015 & $\begin{array}{c}15.600 .0 \\
00\end{array}$ & 1,0 & $\begin{array}{c}15.600 .00 \\
0\end{array}$ \\
\hline 11 & & HONDA & $\begin{array}{c}\text { ACB2J22B303/ } \\
02 \mathrm{~A} / \mathrm{T}\end{array}$ & 2015 & $\begin{array}{c}13.700 .0 \\
00\end{array}$ & 1,0 & $\begin{array}{c}13.700 .00 \\
0\end{array}$ \\
\hline 12 & & HONDA & $\begin{array}{c}\text { GL15C21A07 } \\
\text { MT }\end{array}$ & 2015 & $\begin{array}{c}16.000 .0 \\
00\end{array}$ & 1,0 & $\begin{array}{c}16.000 .00 \\
0\end{array}$ \\
\hline 13 & & HONDA & $\begin{array}{l}\text { ACB2J22B03 } \\
\text { A/T (125 CC) }\end{array}$ & 2014 & $\begin{array}{c}13.100 .0 \\
00 \\
\end{array}$ & 1,0 & $\begin{array}{c}13.100 .00 \\
0 \\
\end{array}$ \\
\hline 14 & & HONDA & $\begin{array}{c}\mathrm{NF} 12 \mathrm{~A} 1 \mathrm{CF} \\
\mathrm{M} / \mathrm{T}\end{array}$ & 2015 & $\begin{array}{c}13.500 .0 \\
00\end{array}$ & 1,0 & $\begin{array}{c}13.500 .00 \\
0\end{array}$ \\
\hline 15 & & HONDA & NF125 TRF & 2014 & $\begin{array}{c}14.500 .0 \\
00\end{array}$ & 1,0 & $\begin{array}{c}14.500 .00 \\
0\end{array}$ \\
\hline
\end{tabular}


ISSN

Untuk mendapatkan besaran PKB yang harus dibayar oleh wajib pajak sesuai dengan bukti tertulis di dalam SKPD yaitu perkalian tarif dengan dasar pengenaan PKB.

$$
\mathrm{PKB}=\mathrm{NJKB} \times \text { Tarif } \mathrm{x} \text { Bobot }
$$

Misalnya : mencari besarnya PKB kendaraan merek HONDA dengan tipe ACB2J22B03 A/T (125 CC) dapat dilihat pada tabel 4.1 No urut 13 dengan NJKB Rp 13.100.000 dengan tarif 1,75\% (kendaraan pribadi kepemilikan pertama) dan bobot 1,0 :

Proses dalam perhitungan PKB yaitu:

1. Petugas akan meng-entry data dan melakukan perekaman data dari wajib pajak tersebut sesuai dengan data yang telah diberikan oleh wajib pajak melalui berkas pendukung seperti bukti identitas dan formulir.

2. Petugas mencari NJKB berdasarkan merek, type dan tahun pembuatan kendaraan didalam data base serta tarif dan bobot bagi jenis kendaraan tersebut.

3. Setelah mendapatkan NJKB dan tarif sesuai dengan urutan kepemilikan maka petugas akan menghitung besarnya PKB untuk kendaraan tersebut.

$\mathrm{PKB}=$ NJKB $\times$ TARIF $\times$ BOBOT

$$
\begin{aligned}
& =\operatorname{Rp} 13.100 .00 \times 1,75 \% \times 1,0 \\
& =\operatorname{Rp} 13.100 .00 \times 0,0175 \times 1,0 \\
& =\operatorname{Rp} 229.250 \times 1,0
\end{aligned}
$$$$
\text { = Rp 229. } 250 \text { ( dapat dilihat pada tabel 2) }
$$

Apabila kendaraan tersebut merupakan kendaraan bermotor baru maka petugas akan menyertakan secara include atau secara keseluruhan biaya BBNKB, SWDKLLJ, biaya STNK dan biaya TNKB kedalam bukti Surat Ketetapan Pajak Daerah (SKPD) atau notice pajak. Tetapi apabila wajib pajak hanya membayar PKB periode atau masa tahun pajak 1 (satu) tahun maka yang dicantumkan dalam notice pajak hanya bukti PKB dan SWDKLLJ. 
Tabel 2. Hasil Perhitungan PKB Roda 2 Pribadi

Berdasarkan NJKB Tahun Pembuatan 2014 dan 2015

\begin{tabular}{|c|c|c|c|c|c|c|c|}
\hline $\begin{array}{l}\mathbf{N} \\
\mathbf{O}\end{array}$ & $\begin{array}{l}\text { KODIN } \\
\text { G }\end{array}$ & $\underset{\mathrm{K}}{\text { MERE }}$ & TYPE & $\begin{array}{l}\text { NJKB } \\
(\mathrm{Rp})\end{array}$ & $\begin{array}{c}\text { Tari } \\
f\end{array}$ & $\underset{T}{\text { BOBO }}$ & $\begin{array}{l}\text { Hasil } \\
\text { PKB } \\
\text { (Rp) }\end{array}$ \\
\hline 1 & $\begin{array}{c}701421 \\
14049\end{array}$ & $\begin{array}{c}\text { YAMAH } \\
\text { A }\end{array}$ & N-MAX (2DP) & $\begin{array}{c}21.200 .00 \\
0\end{array}$ & $\begin{array}{c}1,75 \\
\%\end{array}$ & 1,0 & $\begin{array}{c}371.00 \\
0\end{array}$ \\
\hline 2 & $\begin{array}{c}701421 \\
12949 \\
\end{array}$ & $\begin{array}{c}\text { YAMAH } \\
\text { A }\end{array}$ & BYSON (45P) & $\begin{array}{c}16.900 .00 \\
0\end{array}$ & $\begin{array}{c}1,75 \\
\%\end{array}$ & 1,0 & $\begin{array}{c}295.75 \\
0\end{array}$ \\
\hline 3 & $\begin{array}{c}701421 \\
14349\end{array}$ & $\underset{A}{\text { YAMAH }}$ & $\begin{array}{c}\text { NEW V-IXION } \\
\text { (KICK } \\
\text { STARTER) } \\
\text { (1PA) }\end{array}$ & $\begin{array}{c}18.800 .00 \\
0\end{array}$ & $\begin{array}{c}1,75 \\
\%\end{array}$ & 1,0 & $\begin{array}{c}329.00 \\
0\end{array}$ \\
\hline 4 & $\begin{array}{c}701421 \\
14449 \\
\end{array}$ & $\begin{array}{c}\text { YAMAH } \\
\text { A }\end{array}$ & $\begin{array}{c}\text { OLD V-IXION } \\
(3 C 1)\end{array}$ & $\begin{array}{c}17.300 .00 \\
0 \\
\end{array}$ & $\begin{array}{c}1,75 \\
\%\end{array}$ & 1,0 & $\begin{array}{c}302.75 \\
0 \\
\end{array}$ \\
\hline 5 & $\begin{array}{c}701421 \\
13749\end{array}$ & $\begin{array}{c}\text { YAMAH } \\
\text { A }\end{array}$ & $\begin{array}{c}\text { JUPITER Z1 } \\
\text { CW (UE } 11 \\
\text { CW) }\end{array}$ & $\begin{array}{c}12.400 .00 \\
0\end{array}$ & $\begin{array}{c}1,75 \\
\%\end{array}$ & 1,0 & $\begin{array}{c}217.00 \\
0\end{array}$ \\
\hline 6 & & SUZUKI & UD 110EE & $\begin{array}{c}10.400 .00 \\
0\end{array}$ & $\begin{array}{c}1,75 \\
\%\end{array}$ & 1,0 & $\begin{array}{c}182.00 \\
0\end{array}$ \\
\hline 7 & $\begin{array}{c}701364 \\
32849 \\
\end{array}$ & SUZUKI & UH 200 & $\begin{array}{c}42.400 .00 \\
0\end{array}$ & $\begin{array}{c}1,75 \\
\%\end{array}$ & 1,0 & $\begin{array}{c}742.00 \\
0\end{array}$ \\
\hline 8 & $\begin{array}{c}701364 \\
31649 \\
\end{array}$ & SUZUKI & UK125XCZ & $\begin{array}{c}10.900 .00 \\
0\end{array}$ & $\begin{array}{c}1,75 \\
\%\end{array}$ & 1,0 & $\begin{array}{c}190.75 \\
0\end{array}$ \\
\hline 9 & $\begin{array}{c}701364 \\
31049 \\
\end{array}$ & SUZUKI & FU150SCDZ2 & $\begin{array}{c}15.700 .00 \\
0\end{array}$ & $\begin{array}{c}1,75 \\
\%\end{array}$ & 1,0 & $\begin{array}{c}274.75 \\
0\end{array}$ \\
\hline 10 & $\begin{array}{l}701364 \\
29549\end{array}$ & SUZUKI & FU150SCD3 & $\begin{array}{c}15.600 .00 \\
0\end{array}$ & $\begin{array}{l}1,75 \\
\%\end{array}$ & 1,0 & $\begin{array}{c}273.00 \\
0\end{array}$ \\
\hline 11 & & HONDA & $\begin{array}{c}\text { ACB2J22B03/0 } \\
2 \mathrm{~A} / \mathrm{T}\end{array}$ & $\begin{array}{c}13.700 .00 \\
0\end{array}$ & $\begin{array}{c}1,75 \\
\%\end{array}$ & 1,0 & $\begin{array}{c}239.75 \\
0\end{array}$ \\
\hline 12 & & HONDA & GL15C21A07M & $\begin{array}{c}16.000 .00 \\
0\end{array}$ & $\begin{array}{c}1,75 \\
\%\end{array}$ & 1,0 & $\begin{array}{c}280.00 \\
0\end{array}$ \\
\hline 13 & & HONDA & $\begin{array}{l}\text { ACB2J22B03 } \\
\text { A/T (125 CC) }\end{array}$ & $\begin{array}{c}13.100 .00 \\
0 \\
\end{array}$ & $\begin{array}{c}1,75 \\
\%\end{array}$ & 1,0 & $\begin{array}{c}229.25 \\
0 \\
\end{array}$ \\
\hline 14 & & HONDA & $\begin{array}{c}\text { NF } 12 \text { A1 CF } \\
\mathrm{M} / \mathrm{T}\end{array}$ & $\begin{array}{c}13.500 .00 \\
0\end{array}$ & $\begin{array}{l}1,75 \\
\%\end{array}$ & 1,0 & $\begin{array}{c}236.25 \\
0\end{array}$ \\
\hline 15 & & HONDA & NF125 TRF & $\begin{array}{c}14.500 .00 \\
0\end{array}$ & $\begin{array}{c}1,75 \\
\%\end{array}$ & 1,0 & $\begin{array}{c}253.75 \\
0\end{array}$ \\
\hline
\end{tabular}

Sumber Data : Kantor Samsat Gunungsitoli (2015)

\subsubsection{Faktor Yang Mempengaruhi Peningkatan PKB Pada Kantor Samsat Gunungsitoli}

Berdasarkan hasil wawancara Penulis dengan Kepala Resident Kantor Samsat Gunungsitoli bahwa yang menjadi salah satu faktor dalam meningkatnya pertumbuhan PKB di kantor SAMSAT Gunungsitoli yaitu kesadaran dari wajib pajak atau masyarakat 
pemilik kendaraan bermotor. Selain dari itu faktor ekonomi juga merupakan salah satu penyebab masyarakat tidak membayar pajak dimana lebih mementingkan biaya pendidikan atau biaya lain seperti kebutuhan sehari-hari dari pada membayar PKB. Dari jumlah data unit kendaraan bermotor Roda 2 yang terus bertambah tidak berimbang dengan pajak kendaraan bermotor Roda 2 yang dibayar oleh wajib pajak. Ditambahkan Beliau bahwa PKB Roda 2 menurun setiap tahunnya rata-rata sekitar $30 \%$ (tiga puluh persen) setiap tahunnya.

Tabel 3. Data Jumlah Unit Kendaraan Roda 2 yang Terdaftar di Kantor Samsat Gunungsitoli

\begin{tabular}{|c|l|l|l|l|l|c|}
\hline \multirow{2}{*}{ No } & \multicolumn{1}{|c|}{ Keterangan } & \multicolumn{4}{|c|}{ Tahun Periode } & $\begin{array}{c}\text { Jumlah Unit } \\
\text { Kendaraan } \\
\text { R2 }\end{array}$ \\
\cline { 3 - 6 } & & 2011 & 2012 & 2013 & 2014 & 45.354 \\
\hline 1 & Kota Gunungsitoli & 3.400 & 9.303 & 14.376 & 18.275 & 72.827 \\
\hline 2 & Kabupaten Nias & 40.710 & 27.786 & 2.194 & 2.137 & 8.690 \\
\hline 3 & $\begin{array}{l}\text { Kabupaten Nias } \\
\text { Barat }\end{array}$ & 803 & 1.969 & 1.286 & 4.632 & 7.306 \\
\hline 4 & $\begin{array}{l}\text { Kabupaten Nias } \\
\text { Utara }\end{array}$ & 1.407 & 3.409 & 2.123 & 367 & \\
\hline
\end{tabular}

Sumber Data : Kantor Samsat Gunungsitoli (2015)

\subsubsection{Upaya Dalam Meningkatkan Pajak Daerah melalui PKB Pada Kantor Samsat Gunungsitoli}

Upaya dalam meningkatkan pajak daerah melalui PKB dikantor Samsat Gunungsitoli yaitu meningkatkan SDM yang memadai, profesional dan berkualifikasi. Pemerintah daerah melalui kantor SAMSAT Gunungsitoli berupaya menjalankan fungsinya dalam mengelola dan melaksanakan proses administrasi kendaraan bermotor kepada wajib pajak dengan cara yang cepat dan tepat. Adapun wajib pajak yang harus dilayani adalah wajib pajak yang berada di wilayah kota Gunungsitoli, Kabupaten Nias, Kabupaten Nias Barat dan Kabupaten Nias Utara. Petugas yang melayani wajib pajak harus dapat memberikan kepuasan kepada masyarakat dalam hal ini wajib pajak. Disamping itu petugas juga harus disiplin, terampil, dan bekerjasama dengan berbagai pihak yang terkait dalam menjalankan fungsinya. Selain itu juga pihak instansi melalukan operasi razia kendaraan bermotor minimal dua kali seminggu dan melakukan atau memberi himbauan-himbauan kepada wajib pajak untuk membayar PKB tepat waktu. 


\section{KESIMPULAN (12pt, bold)}

1. Dalam Perhitungan PKB Roda 2 dikantor Samsat Gunungsitoli baik dalam prosedur maupun dalam penerapan tarif PKB telah dilaksanakan sesuai dengan Peraturan Daeran Provinsi Sumatera Utara Nomor 1 Tahun 2011 tentang Pajak Daerah dimana di dalamnya mengatur pajak kendaraan bermotor, selain itu juga telah dilaksanakan sesuai dengan Peraturan Daerah Provinsi Sumatera Utara Nomor 1 Tahun 2015 tentang Pajak Daerah Provinsi Sumatera Utara dengan mengacu pada UU No. 28 Tahun 2009 tentang Pajak Daerah dan Retribusi Daerah.

2. Sistem dan prosedur pemungutan PKB Roda 2 dikantor Samsat Gunungsitoli telah dilaksanakan sesuai dengan standar pelayanan publik kantor bersama samsat. Prosedur dalam pemungutan PKB Roda 2 dikantor Samsat Gunungsitoli dimulai dari pendaftaran oleh pemilik kendaraan, penetapan oleh petugas atas PKB yang dibayar wajib pajak, pembayaran dilakukan oleh wajib pajak dan disetor ke kas daerah melalui bank daerah yaitu Bank SUMUT cabang Gunungsitoli.

3. Pemungutan PKB belum optimal dimana Jumlah kendaraan Roda 2 yang terdaftar dikantor Samsat Gunungsitoli tidak diimbangi dengan Pajak kendaraan yang telah dibayar oleh pemilik kendaraan.

Setelah melakukan penelitian ini, maka disarankan :

1. Ada baiknya menambah sumber daya manusia yang melayani wajib pajak terlebih yang mampu melakukan perhitungan atas PKB.

2. Jangan berhenti untuk selalu menghimbau masyarakat (wajib pajak) untuk patuh serta disiplin dalam melaksanakan kewajibannya membayar pajak serta tidak menggunakan jasa calo. 


\section{DAFTAR PUSTAKA}

Asyari Imam Sapari. 1983. Metedologi Penelitian. Surabaya: Usaha Nasional.

Bobby. (2014). Samsat Gunungsitoli Gelar PeMutihan Pajak Kendaraan Bermotor. http://www.rri.co.id/post/berita/127308/ruang_publik. diperoleh pada tanggal 13 juni 2015

Himpunan Peraturan Tentang Pajak Daerah Dan Retribusi Daerah Beserta Pelaksanaanya. 2011. Jakarta: CV. Tamina Utama.

Machfoedz Ircham. 2010. Metodologi Penelitian Kuantitatif Dan Kualitatif. Yogyakarta: Fitramaya.

Mardiasmo. 2009. Perpajakan.(Rev.ed) Yogyakarta: Andi Yogyakarta.

Silvia. 2012. Pajak Kendaraan Bermotor. http://silviaicha.blogspot.com. diperoleh pada tanggal 13 juni 2015.

Sugiyono. 2016. Metode Penelitian Pendekatan Kuantitatif, Kualitatif dan R\&D. Alfabeta. CV. Bandung

Waluyo. 2013. Perpajakan Indonesia. Salemba Empat-Yogyakarta

\section{Peraturan Gubernur :}

Sulaiman. 2015. Peraturan Daerah Provinsi Sumatera Utara Nomor 1 Tahun 2015 tentang Pajak Daerah Provinsi Sumatera Utara. 